\title{
A new tritylodontid from the Upper Jurassic of Xinjiang, China
}

\author{
Yaoming Hu*, Jin Meng, and James M. Clark \\ Acta Palaeontologica Polonica 54 (3), 2009: 385-391 doi: http://dx.doi.org/10.4202/app.2008.0053
}

A new genus and species of Tritylodontidae, Yuanotherium minor, is described and compared with other known tritylodontids. The new taxon is represented by a partially preserved upper jaw with three postcanines, collected from the upper part of the Shishugou Formation (Oxfordian, Late Jurassic) in the Wucaiwan area of the Junggar Basin, northwestern Xinjiang, China. Like other tritylodontids its maxillary teeth have three rows of blade-like trenchant cusps separated by deep furrows. The new species differs from other tritylodontids mainly in having posteriormost two cusps of the median row on upper postcanines closely placed. The new tritylodontid may have been omnivorous rather than herbivorous, as previously suggested for tritylodontids in general.

Key words: Tritylodontidae, Cynodontia, Upper Jurassic, Xinjiang, China.

Yaoming $\mathrm{Hu}$, Institute of Vertebrate Paleontology and Paleoanthropology, 142

Xiwaidajie, P. O. Box 643, Beijing 100044, China; (*Deceased on April 12th, 2008);

Jin Meng [jmeng@amnh.org], Division of Paleontology, American Museum of Natural History, Central Park West at 79th Street, New York, NY 10024, USA; James C. Clark [jclark@gwu.edu], Department of Biological Sciences, George Washington University Washington DC 20052, USA

This is an open-access article distributed under the terms of the Creative Commons Attribution License (for details please see creativecommons.org), which permits unrestricted use, distribution, and reproduction in any medium, provided the original author and source are credited. 
